\title{
Effect of Post-harvest Treatments on Quality and Shelf Life of Pineapple (Ananas comosus [L.] Merr. ‘Giant Kew') Fruits at Ambient Storage Condition
}

\author{
D. Mandal ${ }^{*}$, Lalremruata ${ }^{2}$, T. K. Hazarika ${ }^{3}$ and B. P. Nautiyal ${ }^{4}$ \\ Dept. of Horticulture, Aromatic and Medicinal Plants, School of Earth Sciences and Natural Resources Management, \\ Mizoram University, Aizawl, Mizoram (796 004), India
}

\section{Article History}

Manuscript No. AR1166

Received in $4^{\text {th }}$ December, 2014

Received in revised form $8^{\text {th }}$ June, 2015

Accepted in final form $28^{\text {th }}$ June, 2015

\section{Correspondence to}

"E-mail: debashismandal1982@gmail.com

\section{Keywords}

Pineapple, gibberellic acid, salicylic acid, ripening, shelf life

\begin{abstract}
The present investigation was taken up at Research Laboratory, Department of Horticulture, Aromatic and Medicinal Plants, Mizoram University, Aizawl to study the effect of nine post-harvest treatments viz., fruit dipping in NAA at $100 \mathrm{mg} \mathrm{L}^{-1}$, gibberellic acid at $100 \mathrm{mg} \mathrm{L}^{-1}$, salicylic acid at $5 \mathrm{mM} \mathrm{L}^{-1}$, covering the fruit with perforated polythene and newspaper bag, fruit coating with wax at $60 \mathrm{~g} \mathrm{~L}^{-1}$, fruit dipping in maleic hydrazide at $500 \mathrm{mg} \mathrm{L}^{-1}$, covering of fruit with dry straw and control, on fruit physico-chemical qualities and shelf life of pineapple cv. Giant Kew. Experiment was laid out in complete randomized design with three replications. Study revealed that among the different treatments, fruits treated with $\mathrm{GA}_{3}$ at $100 \mathrm{mg} \mathrm{L}^{-1}$ showed delayed response of ripening and high shelf life (19.05 days) during storage. At 15 DAS, skin colour remained quarter yellow (average score: 3.2 ), flesh colour remained more white than yellow (average score: 3 ), whereas, fruits showed considerably higher amount of TSS $\left(20.41^{\circ}\right.$ Brix), TSS : acid ratio (20.21), total sugar (13.67\%) and ascorbic acid content (18.49 mg $\left.100 \mathrm{~g} \mathrm{pulp}^{-1}\right)$ with less weight loss (11.61\%) due to this treatment. However, among the other treatments, SA $(5.0 \mathrm{mM})$ performed well in terms of fruit physico-chemical properties and shelf life. SA treated fruits showed less external disease (average score: 1.8 ) and fruit decay (average score: 2.0 ) with high juice content $(71.63 \%)$ and TSS (19.12 ${ }^{\circ}$ Brix) at 15 DAS along with high shelf life (17.05 days).
\end{abstract}

\section{Introduction}

Pineapple, which is known as 'Golden Queen' for its attractive golden yellow colour at ripening and its enticing sugar acid blending, is one of the important tropical fruit crops of India, belongs to Bromeliaceae family and originated in South America. Presently, the crop is cultivated in an area of 105 thousand $\mathrm{h}$ to yield around 1571 thousand $\mathrm{mt}$, which led India as $7^{\text {th }}$ largest pineapple producing country in the world (Anon., 2014). The fruit is rich in sugar, minerals (calcium, iron), organic acids and fairly rich in vitamins (A, B and C). It contains a protein digestive enzyme; bromelain, for what it is potentially used as digestive aid in medicine industry. It is a very important table fruit in South East Asia, Hawaii, Australia and New Zealand. Apart from that it is popularly used in canning and juice industries. Pineapples in fresh fruit market or in transit to canning industries are generally transferred in unrefrigerated condition which led the fruit for faster deterioration in edible quality and neutraceuticals content. Certainly, at ambient condition, enhanced biochemical transformation of starch to sugar made the fruit rich in sugar which consequently gets affected by microbial spoilage. Thus, pineapples have a short post harvest shelf life at ambient temperature and deteriorate quickly ( $\mathrm{Lu}$ et al., 2010). The average minimum loss reported is $21 \%$ and occasional instance estimated of 40 to $50 \%$ and above (Salunkhe and Desai, 1984). This is major short coming in successful trading and export of fresh pineapple fruit. However, cold storage or refrigerated supply is effective at inhibiting the development of decay in pineapple fruit, but symptoms of chilling injury, especially internal browning are observed (Paull and Rohrbach, 1985). Therefore it is of utmost importance to develop a technique for extending the shelf life of pineapple at ambient temperature by reducing the post-harvest decay and maintaining the physicochemical qualities of fruit.

\section{Materials and Methods}

\subsection{Location of experiment}

The experiment was carried out during May-June, 2013, with 
mature green pineapple fruits of cv. Giant Kew obtained from a local grower of Zeipuizau, Aizawl, at Research Laboratory, Department of Horticulture, Aromatic and Medicinal Plants, Mizoram University, stored at $23 \pm 2{ }^{\circ} \mathrm{C}$ temperature and relative humidity of $65 \pm 5 \%$.

\subsection{Treatments}

Nine post harvest treatments viz., fruit dipping in Naphthalene Acetic Acid (NAA) at $100 \mathrm{mg} \mathrm{L}^{-1}\left(\mathrm{~T}_{1}\right)$, Gibberellic Acid $\left(\mathrm{GA}_{3}\right)$ at $100 \mathrm{mg} \mathrm{L}^{-1}\left(\mathrm{~T}_{2}\right)$, Salicylic Acid (SA) at $5 \mathrm{~m} \mathrm{M} \mathrm{L}^{-1}\left(\mathrm{~T}_{3}\right)$ and Maleic Hydrazide $(\mathrm{MH})$ at $500 \mathrm{mg} \mathrm{L}^{-1}\left(\mathrm{~T}_{7}\right)$; covering with perforated polythene $\left(\mathrm{T}_{4}\right)$, newspaper bag $\left(\mathrm{T}_{5}\right)$ and dry straw $\left(\mathrm{T}_{8}\right)$; coating with wax at $60 \mathrm{~g} \mathrm{~L}^{-1}\left(\mathrm{~T}_{6}\right)$ and control (treated with water: $\mathrm{T}_{9}$ ) with three replications were used and statistical analysis was done by following complete randomized design (Gomez and Gomez, 1984).

\subsection{Scoring of visual quality indices}

Following visual quality indices (Table 1) of fruits viz., skin and flesh colour, skin texture, crown condition, flesh translucency, external disease and fruit decay, were recorded as per the standard procedure described by Teisson et al., 1979; Abdullah et al., 1986.

\subsection{Physical and biochemical analysis of fruits}

\subsubsection{Determination of weight loss}

Fruits for each treatment were tagged and weighed at 5 days interval using an electronic balance. The percentage weight loss was calculated by the following equation:

Percentage weight loss at $\mathrm{n}^{\text {th }}$ day $=\frac{\text { weight loss }\left(0 \text { day- } \mathrm{n}^{\text {th }} \text { day }\right)}{\text { Weight at } 0 \text { day }} \times 100$

2.4.2. Determination of decrease (\%) in fruit length and diameter

Fruits for each treatment were tagged and fruit length $(\mathrm{cm})$ and diameter $(\mathrm{cm})$ were measured at 5 days interval by using a digital slide caliper. The per cent decrease in fruit length and diameter were calculated by the following equation:

Per cent decrease at $\mathrm{n}^{\text {th }}$ day $=\frac{\text { length or diameter at }\left(0 \text { day- } \mathrm{n}^{\text {th }} \text { day }\right)}{\text { Length/diameter at } 0 \text { day }} \times 100$ 2.4.3. Determination of juice content (\%)

The percentage of juice content of the fruit pulp was calculated by using the following formula:

Percentage of juice in fruit pulp $=\frac{\text { Wt. of juice }}{\text { Wt. of pulp }} \times 100$

\subsubsection{Biochemical parameters}

Analyses were carried out for biochemical parameters viz., total soluble solids (TSS), total sugar, titrable acidity, TSS: acid ratio and ascorbic acid content following standard procedure described by Ranganna (1997).

\subsection{Shelf life of fruit}

Optimum shelf life (days) of fruits were determined depending on the visual observation of fruit decay, fruit physico-chemical parameters and spoilage and counting the days from harvest to the day with maximum visual score and edible quality.

\section{Results and Discussion}

\subsection{Skin Colour}

Skin colour of pineapple fruits markedly changed during storage. It was observed that from mature green stage, fruit colour gradually intensified through the time of storage (Table 2). Similar findings were mentioned by Wijesinghe and

Table 1: Scores for visual observation with indices

\begin{tabular}{|c|c|c|c|c|c|c|c|}
\hline \multirow[t]{2}{*}{ Score } & \multicolumn{7}{|c|}{ Indices } \\
\hline & Skin colour & Flesh colour & $\begin{array}{l}\text { Skin } \\
\text { texture }\end{array}$ & Crown condition & Flesh translucency & $\begin{array}{l}\text { External } \\
\text { disease }\end{array}$ & $\begin{array}{l}\text { Fruit } \\
\text { decay }\end{array}$ \\
\hline 1. & Mature green & White & $\begin{array}{l}\text { Soggy } \\
\text { and soft }\end{array}$ & $\begin{array}{l}\text { Good fresh and } \\
\text { green }\end{array}$ & $100 \%$ opaque & None & None \\
\hline 2. & $\begin{array}{l}\text { Breaking (begin- } \\
\text { ning to yellow at } \\
\text { the base) }\end{array}$ & $\begin{array}{l}\text { White with trace } \\
\text { of yellow or pale } \\
\text { yellow }\end{array}$ & $\begin{array}{l}\text { Slightly } \\
\text { firm }\end{array}$ & $\begin{array}{l}\text { Good with slightly } \\
\text { yellow at the tips }\end{array}$ & $\begin{array}{l}\text { Opaque with slight translu- } \\
\text { cent (less than } 50 \% \text { ) }\end{array}$ & $\begin{array}{l}\text { Slightly } \\
\text { infected }\end{array}$ & $\begin{array}{l}10 \% \\
\text { decay }\end{array}$ \\
\hline 3. & Quarter yellow & $\begin{array}{l}\text { More white than } \\
\text { yellow }\end{array}$ & $\begin{array}{l}\text { Moder- } \\
\text { ately }\end{array}$ & $\begin{array}{l}\text { Moderate, dry tips } \\
\text { and yellowing }\end{array}$ & $\begin{array}{l}\text { Opaque with moderate } \\
\text { translucent (more than 50\%) }\end{array}$ & $\begin{array}{l}\text { Moderate- } \\
\text { ly infected }\end{array}$ & $\begin{array}{l}25 \% \\
\text { decay }\end{array}$ \\
\hline 4. & Half yellow & Yellow & $\begin{array}{l}\text { Very } \\
\text { firm }\end{array}$ & $\begin{array}{l}\text { Bad, dry tips and } \\
\text { more yellowing }\end{array}$ & $100 \%$ translucent & $\begin{array}{l}\text { Severely } \\
\text { infected }\end{array}$ & $\begin{array}{l}50 \% \\
\text { decay }\end{array}$ \\
\hline 5. & $\begin{array}{l}\text { Three quarter } \\
\text { yellow }\end{array}$ & Golden yellow & & Severe yellowing & & & $\begin{array}{l}75 \% \\
\text { decay }\end{array}$ \\
\hline 6. & Fully yellow & Brownish yellow & & & & & $\begin{array}{l}100 \% \\
\text { decay }\end{array}$ \\
\hline
\end{tabular}


Table 2: Scores of visual quality indices of fruit due to different treatments during storage

\begin{tabular}{|c|c|c|c|c|c|c|c|c|c|c|c|c|c|c|c|c|c|c|c|c|}
\hline \multirow{2}{*}{$\begin{array}{l}\text { Treatments } \\
\text { DAS }\end{array}$} & \multicolumn{4}{|c|}{ Skin colour } & \multicolumn{4}{|c|}{ Flesh colour } & \multicolumn{4}{|c|}{ Skin texture } & \multicolumn{4}{|c|}{ Crown condition } & \multicolumn{4}{|c|}{ Flesh translucency } \\
\hline & 0 & 5 & 10 & 15 & 0 & 5 & 10 & 15 & 0 & 5 & 10 & 15 & 0 & 5 & 10 & 15 & 0 & 5 & 10 & 15 \\
\hline $\begin{array}{l}\mathrm{T}_{1} \text { NAA at } 100 \\
\mathrm{mg} \mathrm{L}^{-1}\end{array}$ & 1.0 & 4.4 & 5.2 & - & 1.0 & 4.0 & 4.6 & - & 4.0 & 2.2 & 2.4 & 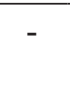 & 1.0 & 1.8 & 3.4 & - & 1.0 & 1.4 & 2.0 & - \\
\hline $\begin{array}{l}\mathrm{T}_{2} \mathrm{GA} 3 \text { at } 100 \\
\mathrm{mg} \mathrm{L}^{-1}\end{array}$ & 1.0 & 1.2 & 1.4 & 3.2 & 1.0 & 1.0 & 2.2 & 3.0 & 4.0 & 4.0 & 4.0 & 3.2 & 1.0 & 1.0 & 1.2 & 2.2 & 1.0 & 1.0 & 1.0 & 1.2 \\
\hline $\mathrm{T}_{3} \mathrm{SA} 5.0 \mathrm{~m} \mathrm{M}$ & 1.0 & 2.0 & 3.2 & 5.4 & 1.0 & 1.2 & 2.8 & 3.2 & 4.0 & 3.8 & 3.2 & 3.0 & 1.0 & 1.2 & 1.8 & 2.4 & 1.0 & 1.0 & 1.0 & 1.8 \\
\hline $\begin{array}{l}\mathrm{T}_{4} \text { Polythene } \\
\text { Bagging }\end{array}$ & 1.0 & 4.6 & 5.4 & - & 1.0 & 3.6 & 4.6 & - & 4.0 & 3.0 & 2.2 & - & 1.0 & 1.8 & 2.8 & - & 1.0 & 1.8 & 1.8 & - \\
\hline $\begin{array}{l}\mathrm{T}_{5} \text { Newspaper } \\
\text { Bagging }\end{array}$ & 1.0 & 4.8 & 5.6 & - & 1.0 & 4.2 & 4.8 & - & 4.0 & 2.4 & 1.6 & - & 1.0 & 2.4 & 3.4 & - & 1.0 & 2.0 & 2.2 & - \\
\hline $\begin{array}{l}\mathrm{T}_{6} \text { Wax Coating at } \\
60 \mathrm{~g} \mathrm{~L}^{-1}\end{array}$ & 1.0 & 2.8 & 4.6 & 5.6 & 1.0 & 1.2 & 3.2 & 3.4 & 4.0 & 4.0 & 3.8 & 2.8 & 1.0 & 2.6 & 3.2 & 3.2 & 1.0 & 1.0 & 1.2 & 1.6 \\
\hline $\begin{array}{l}\mathrm{T}_{7} \mathrm{MH} \text { at } 500 \\
\mathrm{mgL}^{-1}\end{array}$ & 1.0 & 3.0 & 4.0 & 5.0 & 1.0 & 2.4 & 3.8 & 4.4 & 4.0 & 3.6 & 2.8 & 2.6 & 1.0 & 1.4 & 1.4 & 2.0 & 1.0 & 1.2 & 1.4 & 1.8 \\
\hline $\begin{array}{l}\mathrm{T}_{8} \text { Straw } \\
\text { Covering }\end{array}$ & 1.0 & 5.0 & 5.8 & - & 1.0 & 3.8 & 4.8 & - & 4.0 & 2.6 & 2.0 & - & 1.0 & 1.6 & 2.6 & - & 1.0 & 2.8 & 2.8 & - \\
\hline $\mathrm{T}_{9}$ Control & 1.0 & 5.4 & 6.0 & - & 1.0 & 4.6 & 5.0 & - & 4.0 & 2.0 & 1.4 & - & 1.0 & 2.0 & 3.6 & - & 1.0 & 1.8 & 3.0 & - \\
\hline
\end{tabular}

Sarananda (2002). However, the degree of colour break varied among the different treatments. Out of the nine treatments under study, $\mathrm{GA}_{3}$ at $100 \mathrm{mg} \mathrm{L}^{-1}\left(\mathrm{~T}_{2}\right)$ caused retardation of peel colour change (average score: 3.2, quarter yellow; at $15 \mathrm{DAS}$ ). Similar result was reported by Obrero (2006) that GA lengthens shelf life, delay ripening and peel colour change in queen pineapple. It was reported that gibberellins have been found to regulate ageing process in many plant tissues including fruits (Vendrell, 1970). GA caused regreening in citrus fruit (Coggins and Lewis, 1962) and delayed the appearance of red colour pigmentation in tomatoes (Dostal and Leopald, 1967). Even after 15 days of storage of pineapple fruits at room temperature, there were no full colour development of fruit skin, when the fruits were treated with $\mathrm{MH}$ at $500 \mathrm{mg} \mathrm{L}^{-1}$ (average score: 5 , three quarter yellow) or SA at $5.0 \mathrm{~m} \mathrm{M}$ (average score: 5.4, three quarter yellow). Hakim et al. (2013) opined that $\mathrm{GA}_{3}, \mathrm{MH}$ has the ability to retain the total chlorophyll a and chlorophyll $\mathrm{b}$, which caused delaying in colour development in banana fruit. Influence of SA on colour development was reported by Nemeth et al. (2002).

\subsection{Flesh colour}

Generally, flesh colour of pineapple fruit also changed through ripening process. It was recorded that there were consistent increase in flesh colour score during the period of storage. Fruits kept under control attained maximum flesh colour (average score: 5, golden yellow) at 10 DAS (Table 2). Flesh colour of fruit become yellow for $\mathrm{T}_{1}$ (NAA at $100 \mathrm{mg} \mathrm{L}^{-1}$ ), $\mathrm{T}_{4}$ (polythene bagging), $\mathrm{T}_{5}$ (newspaper bagging) and $\mathrm{T}_{8}$ (straw cover) within 10 days of storage. It signified that the fruits got faster ripening within 10 days of storage under these treatments. However, at 15 DAS, flesh colour remained more white than yellow for fruits treated with $\mathrm{GA}_{3}\left(\mathrm{~T}_{2}\right), \mathrm{SA}\left(\mathrm{T}_{3}\right)$ or coated with wax $\left(\mathrm{T}_{6}\right)$ which manifested delaying of ripening. Prasad and Singh (1993) reported that paraffin coating and $\mathrm{GA}_{3}$ delayed ripening in banana.

\subsection{Skin texture}

Firmness of fruit gradually decreases through the period of storage. Present study revealed that fruits at control $\left(T_{9}\right)$ or covered with perforated newspaper bags lost its firmness (average score: 1.4 to 1.6, soggy and soft) within 10 days of storage, whereas, fruits were moderately firm (average score: 3 to 3.2) when treated with $\mathrm{GA}_{3}$ at $100 \mathrm{mg} \mathrm{L}^{-1}\left(\mathrm{~T}_{2}\right)$ or SA at 5.0 $\mathrm{m} \mathrm{M}\left(\mathrm{T}_{3}\right)$, even at 15 DAS (Table 2). Othman (2008) described that fruit firmness decreased as fruit mature. Fruit ripening and softening of vegetative tissues are usually accompanied by catabolism of cell wall polysaccharides (hemicellulose). The breakdown of polymeric carbohydrates, especially pectic substances and hemicelluloses, weaken cell walls and caused reduction in fruit firmness.

\subsection{Crown condition}

It was observed that crown condition was good with slight development of yellow colour at tip in most of the treatments up to 5 DAS. Crown condition score of the fruits was found maximum for control (average score: 3.6, moderate, dry tips and yellowing) at $10 \mathrm{DAS}$, whereas it was relatively low 
(average score: 2-2.2, good with slight tip yellowing) in case of fruits at $\mathrm{T}_{2}$ and $\mathrm{T}_{7}$ even at 15 DAS (Table 2). However, fruits coated with wax at $60 \mathrm{~g} \mathrm{~L}^{-1}\left(\mathrm{~T}_{6}\right)$ showed relatively higher crown condition score (average score: 2.6-3.2) during the storage period. Othman (2008) got similar observation and reported that reduction in crown quality in Gandul pineapple was hastened by paraffin and semper fresh coatings. However, it was opined that crown deterioration is a natural process of senescence and is not a physiological disorder of pineapple. Storage temperature also affected the freshness of crown; the higher the storage temperature, the faster the discolouration of the crown (Abdullah et al., 1985).

\subsection{Flesh translucency}

Fruits at control showed higher flesh translucency (average score: 3 ; more than $50 \%$ translucency) within 10 DAS. Fruits treated with NAA at $100 \mathrm{mg} \mathrm{L}^{-1}$ and covered with perforated newspaper bag or straw showed less than $50 \%$ flesh translucency at 10 DAS (Table 2). However, fruit flesh translucency score was quite low (average score: 1.2 to 1.6, $100 \%$ opaque) in case of the fruits treated with $\mathrm{GA}_{3}$ at $100 \mathrm{mg}$ $\mathrm{L}^{-1}$ or coated with wax at $60 \mathrm{~g} \mathrm{~L}^{-1}$. Flesh translucency is because of electrolyte leakage in the fruit flesh tissue (Chen and Paull, 2011). Othman (2008) reported that paraffin treated fruits were free from flesh translucency during storage.

\subsection{External disease and fruit decay}

At 15 DAS, incidence of external diseases (average score: 4) and fruit decay percentage was found maximum in fruit at control $\left(\mathrm{T}_{9}\right)$. Fruits which were covered either with polythene/ newspaper bag or straw showed severe external infection and high fruit decay score (average score: 5 to 6 ) at 15 DAS (Figure 1 and 2). But the fruits treated with $\mathrm{GA}_{3} 100 \mathrm{mg} \mathrm{L}^{-1}$ or SA at 5.0 $\mathrm{m} \mathrm{M}$ showed significantly less or no external disease infections and fruit decay even at 15 DAS. Sudha et al. (2007) reported that $\mathrm{GA}_{3}$ arrest the growth and spread of micro organisms in Sapota. It was claimed that exogenous application of SA could enhance resistance to pathogen and delay post harvest decay

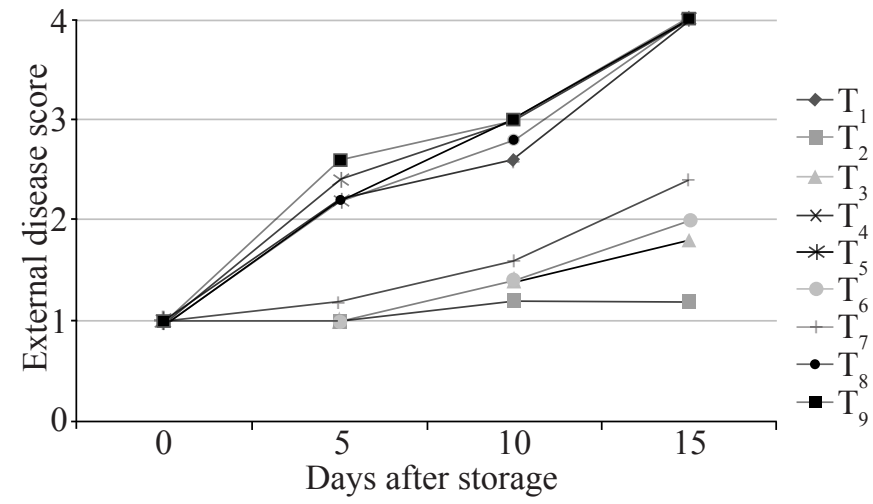

Figure 1: External disease of pineapple fruit during storage
(Asghari et al., 2010; Babalar et al., 2007).

\subsection{Percentage of weight loss, decease in length and diameter,} and juice content

Percentage loss of fruit weight, decrease in fruit length and diameter was found minimum $(11.34 \%, 2.76 \%$ and $2.51 \%)$ in case of fruits coated with wax at $60 \mathrm{~g} \mathrm{~L}^{-1}\left(\mathrm{~T}_{6}\right)$ followed by fruits treated with $\mathrm{GA}_{3}$ at $100 \mathrm{mg} \mathrm{L}^{-1}(11.61 \%, 3.56 \%$ and $3.34 \%$ ) compared with other treatments at 15 DAS (Table 3). Kabir et al. (2010) reported that fruits treated with $\mathrm{GA}_{3} 200$ $\mathrm{mg} \mathrm{L}^{-1}$ were found to have minimum weight loss of pineapple fruits at $16^{\text {th }}$ day of storage. It was observed by Hu et al. (2011) that waxing significantly reduced weight loss of pineapple fruits at storage. Fruit weight loss is mainly associated with respiration and moisture evaporation through the skin. Coating act as barriers, thereby restricting water transfer and protecting fruit skin from mechanical injuries and delayed dehydration (Hernandezmunoz et al., 2008). Juice content of the pineapple fruit increased along the period of storage in all the treatments. Dhar et al. (2008) got similar observation in pineapple cv. Giant Kew at Bangladesh. Though in the present study, juice content gradually increased, however, it remained low $(71.63 \%$ and $72.09 \%)$ in case of fruits treated with SA $\left(\mathrm{T}_{3}\right)$ or $\mathrm{GA}_{3}\left(\mathrm{~T}_{2}\right)$ compared with other treatments at 15 DAS (Table 4), which signified delaying of fruit ripening under these treatments, as ripening accelerates the juice content of pineapple fruit (Othman, 2008).

\subsection{Biochemical parameters}

Except fruits at control, for the other treatments, total sugar and TSS content gradually increased up to 5 DAS and afterward declined. However, fruits under $\mathrm{T}_{2}, \mathrm{~T}_{3}$ and $\mathrm{T}_{6}$ showed increase up to 10 DAS (Table 4 and 5). Kabir et al. (2010) also had similar kind of increase in TSS and total sugar content of pineapple fruit up to 12 DAS at ambient storage. During the storage period pineapple fruits showed increased acidity concurred with the earlier reporting of Paull (1997). However, titratable acidity was found low (1.01 and $1.02 \%)$ in fruits

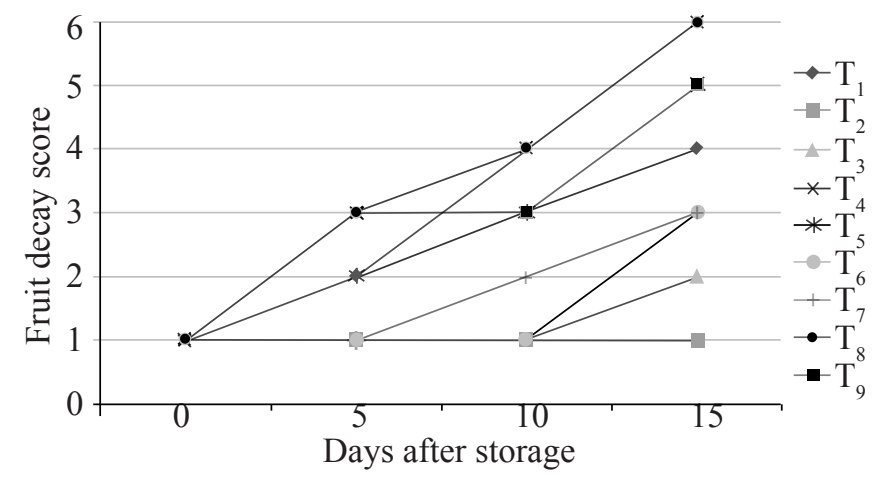

Figure 2: Fruit decay of pineapple during storage 


\begin{tabular}{|c|c|c|c|c|c|c|c|c|c|c|c|c|}
\hline \multirow[t]{2}{*}{ Treatments } & \multicolumn{4}{|c|}{ Weight loss (\%) at DAS } & \multicolumn{4}{|c|}{ Length decrease (\%) at DAS } & \multicolumn{4}{|c|}{ Diameter decrease $(\%)$ at DAS } \\
\hline & 0 & 5 & 10 & 15 & 0 & 5 & 10 & 15 & 0 & 5 & 10 & 15 \\
\hline $\begin{array}{l}\mathrm{T}_{1} \mathrm{NAA} \text { at } \\
100 \mathrm{mg} \mathrm{L}^{-1}\end{array}$ & 0.00 & 6.54 & 11.21 & - & $\begin{array}{c}0.00 \\
(1.28)\end{array}$ & $\begin{array}{c}4.09 \\
(11.66)\end{array}$ & $\begin{array}{c}5.62 \\
(13.71)\end{array}$ & - & $\begin{array}{c}0.00 \\
(1.28)\end{array}$ & $\begin{array}{c}3.80 \\
(11.24)\end{array}$ & $\begin{array}{c}5.36 \\
(13.39)\end{array}$ & - \\
\hline $\begin{array}{l}\mathrm{T}_{2} \mathrm{GA} 3 \text { at } 100 \\
\mathrm{mg} \mathrm{L}^{-1}\end{array}$ & 0.00 & 2.68 & 7.14 & 11.61 & $\begin{array}{c}0.00 \\
(1.28)\end{array}$ & $\begin{array}{l}1.56 \\
(7.17)\end{array}$ & $\begin{array}{c}2.52 \\
(9.14)\end{array}$ & $\begin{array}{c}3.56 \\
(10.88)\end{array}$ & $\begin{array}{c}0.00 \\
(1.28)\end{array}$ & $\begin{array}{c}1.33 \\
(6.63)\end{array}$ & $\begin{array}{c}2.29 \\
(8.70)\end{array}$ & $\begin{array}{c}3.34 \\
(10.52)\end{array}$ \\
\hline $\begin{array}{l}\mathrm{T}_{3} \mathrm{SA} 5.0 \mathrm{~m} \\
\mathrm{M}\end{array}$ & 0.00 & 3.48 & 8.70 & 13.04 & $\begin{array}{c}0.00 \\
(1.28)\end{array}$ & $\begin{array}{c}2.59 \\
(9.27)\end{array}$ & $\begin{array}{c}3.50 \\
(10.79)\end{array}$ & $\begin{array}{c}5.26 \\
(13.25)\end{array}$ & $\begin{array}{c}0.00 \\
(1.28)\end{array}$ & $\begin{array}{c}2.36 \\
(8.85)\end{array}$ & $\begin{array}{c}3.25 \\
(10.39)\end{array}$ & $\begin{array}{c}4.43 \\
(12.16)\end{array}$ \\
\hline $\begin{array}{l}\mathrm{T}_{4} \text { Polythene } \\
\text { Bagging }\end{array}$ & 0.00 & 5.22 & 10.43 & - & $\begin{array}{c}0.00 \\
(1.28)\end{array}$ & $\begin{array}{c}3.36 \\
(10.56)\end{array}$ & $\begin{array}{c}4.44 \\
(12.16)\end{array}$ & - & $\begin{array}{c}0.00 \\
(1.28)\end{array}$ & $\begin{array}{c}3.12 \\
(10.17)\end{array}$ & $\begin{array}{c}4.29 \\
(11.95)\end{array}$ & - \\
\hline $\begin{array}{l}\mathrm{T}_{5} \text { Newspaper } \\
\text { Bagging }\end{array}$ & 0.00 & 6.42 & 11.93 & - & $\begin{array}{c}0.00 \\
(1.28)\end{array}$ & $\begin{array}{c}3.87 \\
(11.34)\end{array}$ & $\begin{array}{c}5.50 \\
(13.56)\end{array}$ & - & $\begin{array}{c}0.00 \\
(1.28)\end{array}$ & $\begin{array}{c}3.71 \\
(11.10)\end{array}$ & $\begin{array}{c}4.91 \\
(12.80)\end{array}$ & - \\
\hline $\begin{array}{l}\mathrm{T}_{6} \text { Wax Coat- } \\
\text { ing at } 60 \mathrm{~g} \mathrm{~L}^{-1}\end{array}$ & 0.00 & 2.06 & 7.22 & 11.34 & $\begin{array}{c}0.00 \\
(1.28)\end{array}$ & $\begin{array}{c}1.07 \\
(5.94)\end{array}$ & $\begin{array}{c}2.07 \\
(8.26)\end{array}$ & $\begin{array}{c}2.76 \\
(9.55)\end{array}$ & $\begin{array}{c}0.00 \\
(1.28)\end{array}$ & $\begin{array}{c}1.05 \\
(5.87)\end{array}$ & $\begin{array}{c}1.88 \\
(7.89)\end{array}$ & $\begin{array}{c}2.51 \\
(9.12)\end{array}$ \\
\hline $\begin{array}{l}\mathrm{T}_{7} \mathrm{MH} \text { at } 500 \\
\mathrm{mg} \mathrm{L}^{-1}\end{array}$ & 0.00 & 5.04 & 9.24 & 12.61 & $\begin{array}{c}0.00 \\
(1.28)\end{array}$ & $\begin{array}{c}2.81 \\
(9.65)\end{array}$ & $\begin{array}{c}3.55 \\
(10.86)\end{array}$ & $\begin{array}{c}5.69 \\
(13.80)\end{array}$ & $\begin{array}{c}0.00 \\
(1.28)\end{array}$ & $\begin{array}{c}2.63 \\
(9.33)\end{array}$ & $\begin{array}{c}3.29 \\
(10.44)\end{array}$ & $\begin{array}{c}4.79 \\
(12.64)\end{array}$ \\
\hline $\begin{array}{l}\mathrm{T}_{8} \text { Straw } \\
\text { Covering }\end{array}$ & 0.00 & 7.34 & 12.84 & - & $\begin{array}{c}0.00 \\
(1.28)\end{array}$ & $\begin{array}{c}5.84 \\
(13.98)\end{array}$ & $\begin{array}{c}6.59 \\
(14.88)\end{array}$ & - & $\begin{array}{c}0.00 \\
(1.28)\end{array}$ & $\begin{array}{c}3.85 \\
(11.32)\end{array}$ & $\begin{array}{c}5.39 \\
(13.43)\end{array}$ & - \\
\hline $\mathrm{T}_{9}$ Control & 0.00 & 8.85 & 14.16 & - & $\begin{array}{c}0.00 \\
(1.28)\end{array}$ & $\begin{array}{c}6.32 \\
(14.56)\end{array}$ & $\begin{array}{c}6.86 \\
(15.19)\end{array}$ & - & $\begin{array}{c}0.00 \\
(1.28)\end{array}$ & $\begin{array}{c}5.25 \\
(13.25)\end{array}$ & $\begin{array}{c}6.45 \\
(14.71)\end{array}$ & - \\
\hline $\mathrm{SEm} \pm$ & - & 0.3592 & 0.2710 & - & - & 0.2736 & 0.1965 & - & - & 0.6370 & 0.4482 & - \\
\hline $\mathrm{CD}(p=0.05)$ & - & 0.7546 & 0.5694 & - & - & 0.5749 & 0.4128 & - & - & 1.3382 & 0.9417 & - \\
\hline
\end{tabular}

${ }^{*}$ Angular transformed value in parenthesis

Table 4: Effect of post-harvest treatments on percentage of juice content, total sugar and ascorbic acid content of fruit during storage

\begin{tabular}{|c|c|c|c|c|c|c|c|c|c|c|c|c|}
\hline \multirow[t]{2}{*}{ Treatments } & \multicolumn{4}{|c|}{ Juice content $(\%)$ at DAS } & \multicolumn{4}{|c|}{ Total sugar (\%) at DAS } & \multicolumn{4}{|c|}{$\begin{array}{c}\text { Ascorbic acid (mg/100 g pulp) } \\
\text { at DAS }\end{array}$} \\
\hline & 0 & 5 & 10 & 15 & 0 & 5 & 10 & 15 & 0 & 5 & 10 & 15 \\
\hline $\mathrm{T}_{1} \mathrm{NAA}$ at $100 \mathrm{mg} \mathrm{L}^{-1}$ & 63.48 & 68.96 & 72.36 & - & 11.78 & 12.52 & 12.36 & - & 20.52 & 17.92 & 15.82 & - \\
\hline $\mathrm{T}_{2} \mathrm{GA} 3$ at $100 \mathrm{mg} \mathrm{L}^{-1}$ & 64.59 & 67.42 & 69.13 & 72.09 & 12.53 & 13.36 & 14.38 & 13.67 & 22.73 & 21.78 & 20.21 & 18.49 \\
\hline $\mathrm{T}_{3} \mathrm{SA} 5.0 \mathrm{~m} \mathrm{M}$ & 63.94 & 67.13 & 70.24 & 71.63 & 12.59 & 13.28 & 13.78 & 13.32 & 23.14 & 20.83 & 19.62 & 16.85 \\
\hline $\mathrm{T}_{4}$ Polythene bagging & 65.27 & 69.08 & 70.45 & - & 11.81 & 12.53 & 11.79 & - & 20.16 & 16.74 & 14.83 & - \\
\hline $\mathrm{T}_{5}$ Newspaper bagging & 63.56 & 68.37 & 71.26 & - & 11.13 & 11.76 & 11.58 & - & 19.29 & 15.82 & 13.68 & - \\
\hline $\begin{array}{l}\mathrm{T}_{6} \text { Wax coating at } 60 \\
\mathrm{~g} \mathrm{~L}^{-1}\end{array}$ & 64.21 & 68.06 & 71.42 & 73.47 & 12.49 & 13.39 & 13.25 & 13.18 & 19.86 & 16.23 & 14.39 & 11.83 \\
\hline $\mathrm{T}_{7} \mathrm{MH}$ at $500 \mathrm{mg} \mathrm{L}^{-1}$ & 65.63 & 68.19 & 70.53 & 72.92 & 11.86 & 12.54 & 12.42 & 12.27 & 20.39 & 19.53 & 17.13 & 14.87 \\
\hline $\mathrm{T}_{8}$ Straw covering & 63.84 & 68.26 & 71.22 & - & 10.09 & 10.61 & 10.49 & - & 18.86 & 14.82 & 12.29 & - \\
\hline $\mathrm{T}_{9}$ Control & 65.43 & 69.56 & 71.08 & - & 11.18 & 11.64 & 10.23 & - & 18.92 & 13.69 & 11.28 & - \\
\hline $\mathrm{SEm} \pm$ & 0.3997 & 0.3864 & 0.4468 & - & 0.1843 & 0.1541 & 0.4873 & - & 0.6228 & 0.4697 & 0.4957 & - \\
\hline $\mathrm{CD}(p=0.05)$ & 0.8398 & 0.8119 & 0.9387 & - & 0.3161 & 0.2643 & 0.8360 & - & 1.3084 & 0.9869 & 1.0415 & - \\
\hline
\end{tabular}

treated with $\mathrm{GA}_{3}$ or SA at 15 DAS. Ascorbic acid content of the fruit was maximum (18.86 to $\left.23.14 \mathrm{mg} 100 \mathrm{~g} \mathrm{pulp}^{-1}\right)$ on 0 DAS and it declined afterwards. Adisa (1986) noticed that ascorbic acid content of pineapple gradually decreased with the increase in storage period. In terms of biochemical parameters, fruits treated with $\mathrm{GA}_{3}$ at $100 \mathrm{mg} \mathrm{L}^{-1}$ showed higher amount of TSS $\left(20.41^{\circ}\right.$ Brix), TSS : acid ratio (20.21), total sugar

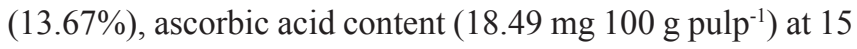


Table 5: Effect of post-harvest treatments on changes in total soluble solid, titratable acidity and their ratio of pineapple fruit during storage

\begin{tabular}{|c|c|c|c|c|c|c|c|c|c|c|c|c|}
\hline \multirow[t]{2}{*}{ Treatments } & \multicolumn{4}{|c|}{ TSS ( ${ }^{\circ}$ Brix) at DAS } & \multicolumn{4}{|c|}{ Titratable acidity (\%) at DAS } & \multicolumn{4}{|c|}{ TSS: Acid ratio at DAS } \\
\hline & 0 & 5 & 10 & 15 & 0 & 5 & 10 & 15 & 0 & 5 & 10 & 15 \\
\hline $\mathrm{T}_{1} \mathrm{NAA}$ at $100 \mathrm{mg} \mathrm{L}^{-1}$ & 15.80 & 17.32 & 14.46 & - & 1.09 & 1.18 & 1.22 & - & 14.50 & 14.68 & 11.85 & - \\
\hline $\mathrm{T}_{2} \mathrm{GA} 3$ at $100 \mathrm{mg} \mathrm{L}^{-1}$ & 16.76 & 18.81 & 20.52 & 20.41 & 0.89 & 0.96 & 0.98 & 1.01 & 18.83 & 19.59 & 20.94 & 20.21 \\
\hline $\mathrm{T}_{3} \mathrm{SA} 5.0 \mathrm{~m} \mathrm{M}$ & 16.43 & 17.78 & 19.42 & 19.12 & 0.84 & 0.87 & 0.91 & 1.02 & 19.56 & 20.44 & 21.34 & 18.75 \\
\hline $\mathrm{T}_{4}$ Polythene Bagging & 15.71 & 18.23 & 17.21 & - & 0.98 & 1.11 & 1.21 & - & 16.03 & 16.42 & 14.22 & - \\
\hline $\mathrm{T}_{5}$ Newspaper Bagging & 16.25 & 16.79 & 15.56 & - & 1.02 & 1.14 & 1.21 & - & 15.93 & 14.73 & 12.86 & - \\
\hline $\begin{array}{l}\mathrm{T}_{6} \text { Wax Coating at } 60 \\
\mathrm{~g} \mathrm{~L}^{-1}\end{array}$ & 16.47 & 17.26 & 17.82 & 17.64 & 1.05 & 1.09 & 1.15 & 1.18 & 15.69 & 15.83 & 15.50 & 14.95 \\
\hline $\mathrm{T}_{7} \mathrm{MH}$ at $500 \mathrm{mg} \mathrm{L}^{-1}$ & 16.40 & 17.75 & 17.29 & 17.09 & 0.92 & 1.01 & 1.14 & 1.19 & 17.83 & 17.57 & 15.17 & 14.36 \\
\hline $\mathrm{T}_{8}$ Straw Covering & 15.49 & 17.02 & 16.43 & - & 0.98 & 1.01 & 1.12 & - & 15.81 & 16.85 & 14.67 & - \\
\hline $\mathrm{T}_{9}$ Control & 16.85 & 15.83 & 13.08 & - & 1.01 & 1.19 & 1.31 & - & 16.68 & 13.30 & 9.98 & - \\
\hline $\mathrm{SEm} \pm$ & 0.2213 & 0.4605 & 0.7607 & - & 0.1093 & 0.0442 & 0.0409 & - & 0.3770 & 0.5818 & 0.5648 & - \\
\hline $\mathrm{CD}(p=0.05)$ & 0.3796 & 0.7900 & 1.3049 & - & 0.1875 & 0.0759 & 0.0702 & - & 0.6467 & 0.9981 & 0.9689 & - \\
\hline
\end{tabular}

DAS. Kabir et al. (2010) also found high TSS, total sugar and ascorbic acid content of pineapple fruits treated with $\mathrm{GA}_{3}$ at $300 \mathrm{mg} \mathrm{L}^{-1}$ during ambient storage.

\subsection{Shelf life}

There were significant variations in shelf life of the pineapple due to different treatment under study (Figure 3). Maximum shelf life (19.05 days) was observed in case of the fruits treated with $\mathrm{GA}_{3}\left(\mathrm{~T}_{2}\right)$ followed by $\mathrm{T}_{3}$ i.e. treated with $\mathrm{SA}$ at $5.0 \mathrm{~m} \mathrm{M}$ (17.05 days) compared with control (10.30 days). Dhar et al. (2008) reported $\mathrm{GA}_{3}\left(100 \mathrm{mg} \mathrm{L}^{-1}\right)$ treated pineapple fruits got 20.77 days of shelf life when kept under room temperature. Gholami et al. (2010) reported that $\mathrm{GA}_{3}$ treated sweet cherry fruit got delayed ripening as it decreased the ethylene production. Hakim et al. (2013) observed maximum shelf life (13.0 days) in banana fruit when treated with $\mathrm{GA}_{3}$ at $400 \mathrm{ppm}$. Lu et al. (2010) observed that post harvest treatment with 5.0 $\mathrm{m}$ M SA delayed ripening and extended shelf life of pineapple cv. Comte de Paris.

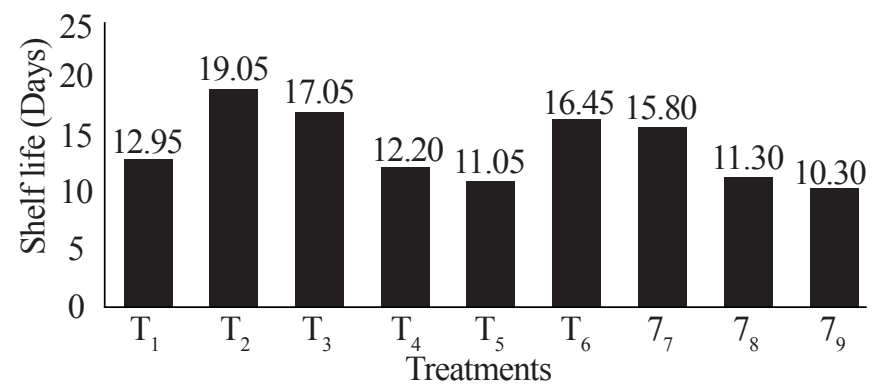

Figure 3: Shelf life of pineapple fruits under different postharvest treatments

\section{Conclusion}

The result of the present experiment showed that $\mathrm{GA}_{3}$ at $100 \mathrm{mg} \mathrm{L}^{-1}$ as the best post harvest treatment to extend the shelf life while maintaining the fruit physico-chemical qualities of Pineapple cv. Giant Kew during storage at room temperature.

\section{References}

Abdullah, H., Rohaya, M.A., Zaipun, M.Z., 1986. Storage study of pineapples (Ananas comosus cv. sarawak) with special emphasis on black heart disorder. Malaysian Agricultural Research and Development Institute Research Bulletin 14(2), 132-138.

Adisa, V.A., 1986. The influence of molds and some storage factors on the ascorbic acid content of orange and pineapple fruits. Food Chemistry 22, 139-146.

Anonymous, 2014. Indian Horticulture Database 2013. National Horticulture Board, Ministry of Agriculture, Govt. of India, 106-249.

Asghari, M., Aghdam, M.S., 2010. Impact of salicylic acid on post harvest physiology of horticultural crops. Trends in Food Science and Technology 21, 502-509.

Babalar, M., Asghari, M., Talaei, A., Khosroshahi, A., 2007. Effect of pre and post harvest salicylic acid treatment on ethylene production, fungal decay and overall quality of selva strawberry fruit. Food Chemistry 105, 449-453.

Chen, C.C., Paull, R.E., 2001. Fruit temperature and crown removal on the occurrence of pineapple fruit translucency. Scientia Horticulturae 88, 85-95. 
Coggins, C.W., Lewis, L.N., 1962. Regression of Valencia Orange as influenced by potassium gibberellate. Plant Physiology 37, 625-627.

Dhar, M., Rahman, S.M., Sayem, S.M., 2008. Maturity and post harvest study of pineapple with quality and shelf life under red soil. International Journal of Sustainable Crop Production 3, 69-75.

Dostal, H.C., Leopold, A.C., 1967. Gibberellin delays ripening of tomatoes. Science 158, 1579-1580.

Gholami, M., Sedighi, A., Ershadi, A., Sarikhani, H., 2010. Effect of pre and post harvest treatments of salicylic and gibberellic acid on ripening and some physiochemical properties of 'Mashhad' sweet cherry (Prunus avium L.) fruit. Acta Horticulturae 884, 257-264.

Gomez, K.A., Gomez, A.A., 1984. Statistical Procedure for Agricultural Research (2nd Edn.). John Willey and Sons, Inc., New York, 8-19.

Hakim, K.A., Sarkar, M.A.R., Khan, M.Z.H., Rahman, S.M., Ibrahim, M., Islam, M.K., 2013. Effect of post harvest treatments on physiochemical characters during storage of two banana (Musa spp.) cv. Sabri and Amritasagar. International Journal of Biosciences 3, 168-179.

Hernandezmunoz, P., Almenar, E, Valle, V., Velez, D., Gavara, R., 2008. Effect of chitosan coating combined with post harvest calcium treatment on strawberry (Fragaria $x$ ananassa) quality during refrigerated storage. Food Chemistry 110, 428-435.

Hu, H., Li, X., Dong, C., Chen, W., 2011. Effect of wax treatment on quality and post harvest physiology of pineapple fruit in cold storage. African Journal of Biotechnology 10, 7592-7603.

Kabir, H., Howlader, J., Ghosh, T.K., Goswami, C., Haque, M.A., 2010. Effect of different maturity phases and post harvest treatments on the shelf life of pineapple. International Journal of Bio Research 2, 11-16.

Lu, X.H., Sun. D.Q., Xi, Y.W.M., Sun, G.M., 2010. Effect of post harvest salicylic acid treatment on fruit quality and anti-oxidant metabolism in pineapple during cold storage. The Journal of Horticultural Science and Biotechnology $85,454-458$.
Nemeth, M., Janda, T., Horvath, E., Paldi, E., Szalai, G., 2002. Exogenous salicylic acid increase polyamine content but may decrease drought tolerance in maize. Plant Science $162,569-574$.

Obrero, I.Q., 2006. Yield response of Queen Pineapple to the application of Gibberellic Acid. Pineapple News $15,6-7$.

Othman, Z., 2008. Effect of post harvest coatings and heat treatment on quality of stored pineapple fruits. Ph. D. Thesis, University of Putra, Malaysia, 98-309.

Paull, R.E., 1997. Pineapple. In: Mitra, S.K. (Ed.), Postharvest physiology and storage of tropical and subtropical fruits. CAB International, Wallingford, UK, 123-143.

Paull, R.E., Rohrbach, K.G., 1985. Symptom development of chilling injury in pineapple fruit. Journal of the American Society for Horticultural Science 110, 100-105.

Prasad, M.M., Singh, H.N.P., 1993. Effect of hormones on longevity of banana fruits. National Academy Science Letters 16, 59-62.

Ranganna, S., 1997. Handbook of Analysis and Quality Control for Fruits and Vegetable Products. Tata McGraw Hill Publishing Co. Ltd., New Delhi, 875-886.

Salunkhe, D.H., Desai, B.B., 1984. Post Harvest Biotechnology of Fruits (Vol. 2). CRC Press Inc. Boca Roton, Florida, 194.

Sudha, R., Amutha, R., Muthulaksmi, S., Baby Rani, W., Indira, K., Mareeswari, P., 2007. Influence of pre and post harvest chemical treatments on physical characteristics of sapota (Achras sapota L.) var. PKM1. Research Journal of Agriculture and Biological Sciences 3, 450-452.

Teisson, C., Combres, J.C., Martin- Pervel, P., Marchal, J., 1979. Internal browning of pineapple: 11 -symptoms, iv -biochemical approach. Fruits 34(5), 315-338.

Vendrell, M., 1970. Acceleration and delay of ripening in banana fruit tissue by gibberellic acid. Australian Journal of Biological Sciences 23, 553-559.

Wijesinghe, W.A.J.P., Sarananda, K.H., 2002. Post harvest quality of 'Mauritius' pineapple and reasons for reduced quality. International Journal of Tropical Agricultural Research and Extension 5, 53-56. 